\title{
The Regiment of Women: Neo-Edwardian suffrage narratives and women writers of the 1910s
}

\section{Sarah Edwards}

School of Humanities, University of Strathclyde, Glasgow, UK

Level 4, Lord Hope Building, 141 St James Road, Glasgow G3 0LT

sarah.m.edwards@strath.ac.uk

Dr Sarah Edwards is Senior Lecturer in English Studies at the University of Strathclyde. Her research interests are in Edwardian and neo-Edwardian literature and culture, life writing, and the architectural humanities. Her publications include Writing the Modern City: literature, architecture, modernity (Routledge, 2011, with Jonathan Charley), Nostalgia in the TwentyFirst Century (special issue of Consumption, Markets and Culture, 2014, with Kathy Hamilton et al.), and articles in Women's History Review, Women's Writing and Life Writing. 


\title{
The Regiment of Women: Neo-Edwardian suffrage narratives and women writers of the 1910s
}

\begin{abstract}
This essay will re-evaluate several women writers of the 1910s as neo-Edwardian writers, by examining a range of fictional and autobiographical texts that are set in the recent past of the Edwardian period. It will focus in particular on three suffragette narratives that were published in the pre-World War One years - Constance Maud, No Surrender (1911), Gertrude Colmore, Suffragette Sally (1911) and Lady Constance Lytton, Prisons and Prisoners: some personal experiences (1914) - that seek to represent, and evaluate, the movement's activities during the Edwardian decade and which have not yet been the subject of sustained critical comparison. By identifying some distinctive formal and thematic tropes in these texts, I aim to explore their continuing interest to different scholarly communities and to develop a fresh reading of these works' literary, and wider cultural and social, provenance as neo-Edwardian texts.
\end{abstract}

Keywords: neo-Edwardian; suffragette narratives; autobiography; 1910s 


\section{Introduction}

This essay will re-evaluate several women writers of the 1910s as neo-Edwardian writers, by examining a range of fictional and autobiographical texts that are set in the recent past of the Edwardian period. It will focus in particular on three suffragette narratives that were published in the pre-World War One years - Constance Maud, No Surrender (1911), Gertrude Colmore, Suffragette Sally (1911) and Lady Constance Lytton, Prisons and Prisoners: some personal experiences (1914) - that seek to represent, and evaluate, the movement's activities during the Edwardian decade. Before the publication of Lytton's autobiographical narrative, the novels Suffragette Sally and No Surrender had presented fictionalised versions of Lytton's controversial imprisonment when she famously disguised herself as a working-class woman, "Jane Warton, Spinster", to expose discriminatory treatment of suffragettes. Both literary critics, and social and cultural historians, have sought to examine the representational strategies of these texts, in light of interdisciplinary feminist work on the construction of suffragette identities. However, these three works have not been the subject of sustained critical comparison, although the inter-textual relationships between the novels and an autobiographical narrative which became a model for later suffrage autobiography, provide illuminating insights into the range of textual strategies that were used to explore new femininities in the Georgian, pre-war years. ${ }^{1}$ By identifying some distinctive formal and thematic tropes in these texts, I aim to explore their continuing interest to different scholarly communities and to develop a fresh reading of these works' literary, and wider cultural and social, provenance as neo-Edwardian texts. ${ }^{2}$

\section{The neo-Edwardian text and suffragette fiction}

Neo-Edwardian texts constitute an ongoing literary tradition that began around 1910, in their evocation of an Edwardian age whose chronology is variously dated from the mid-1890s to 
1914. ${ }^{3}$ Like the adjacent, and more widely-discussed, neo-Victorian narrative, neoEdwardian works critically re-interpret, re-discover and revise dominant discourses of the Edwardian period, rather than simply being located in this period. ${ }^{4}$ Therefore, familiar tropes in the Edwardian novel - the country house, the long hot summer, the Golden Age motif, and the suffragette - are subjected to critical scrutiny. ${ }^{5}$ Many works are precisely dated, and this is evident, for example, in Suffragette Sally, where such signposting often occurs at the beginning of chapters: "it is well to feed the hungry, and so, and thus, in His Majesty's prisons, in the years of grace 1909 and 1910, prisoners, who adopted the hunger strike, were fed". ${ }^{6}$ By employing such devices, these works trace change and development within a relatively short era. Hence, the works often feature characters that change rapidly in several years, such as children and adolescents, or - in the case of suffragette fictions - adults who experience sudden shifts in identity in response to turbulent changes in their wider political and social status. In suffragette fiction, the frequent use of the present tense reinforces a sense of immediacy, promotes identification, and indicates that the text is specifically situated within the context of a political movement in process. At the end of chapter nine in Suffragette Sally, for example, the middle-class convert Edith recalls of a concert that she "has that programme still" which "bring(s) to her mind all the pain and joy...the stress, the strain and struggle and turmoil associated with the women's movement in the first years of the twentieth century". Neo-Edwardian texts often include framing devices that probe conventional chronological markers, and Colmore thus subverts conventional narrative closure by adding an "Author's Note" to her novel which functions both to memorialise the end-date of her suffragette narrative (23 February 1911), while also stating that "this is a story which cannot be finished now". 7

Many neo-Edwardian novels mirror Edwardian narrative forms, are grounded in realist aesthetics and employ a third-person narrator, but - like Colmore's and Maud's novels 
- also feature multiple perspectives via free indirect discourse, set-pieces that feature lectures or political speeches, or by inserting life writings, such as journal entries and letters.

However, in general, neo-Edwardian and suffragette novels do not privilege interiority - like Lytton's autobiographical narrative - but instead display what I will term the "extraverted self", or the individual in relation with others. ${ }^{8}$ This interaction takes a variety of forms: the intertwining of public and private histories when an individual is caught up in a major historical event, such as the 1901 and 1911 Coronations, or - in the case of suffragette narratives - the 1910 Black Friday march. ${ }^{9}$ In such episodes, there is a narrative focus on immediate reactions, and on actions which drive the plot forward, within a crowd or demonstration, than on the detailed rendition of inner consciousness. These features combine to privilege a sense of historicity and social realism within the novel. Similarly to Colmore, Maud grafted onto her novel a Preface about her work's perceived relationship to history, in which she privileged "suffragette literature of an historical or biographical nature" as genres to which her novel, "only a work of fiction" did not aspire to illuminate, yet justifying its publication on the grounds that "though this book is entirely fiction as far as the characters are concerned, the latter move among events that are historically real and true". ${ }^{10}$

Critics of suffragette fiction, such as Sowon Park and Sos Eltis, note that these works are "grounded in what they presented as an accurate reading of reality", but that they are, nevertheless, complex literary texts that develop new formal and thematic structures "to challenge established social structures and class hierarchies". ${ }^{11}$ In the context of wider literary developments, and contemporary debates around definitions of modernity and modernism, Jane Eldridge Miller's analysis of suffrage works' "modernism of content" - or her repudiation of earlier feminist critics' dismissal of their apparent lack of formal innovation - is a valuable re-assessment of women's fictions as “unique expressions of a particular moment in history that need to be understood on their own terms" with a modern 
political agenda that defies modernist ideals of "traditional literary timelessness or universality" and aesthetic experimentation. ${ }^{12}$ However, I depart from Miller's conclusion that distinctions between Edwardian and Georgian women's writing are "not particularly useful for discussions of fiction produced during the period". ${ }^{13}$ The suffragette texts which are considered in this essay were written from 1911, but contained new narratives of the pre1911 decade and created new epiphanic moments from emerging suffragette narratives. This work, then, contributes to new feminist modernist studies by tracing a female literary tradition that critically re-writes modern culture, its material and social determinants, and its recent recontextualisations by feminist scholars. ${ }^{14}$

\section{Neo-Edwardian fictional women: angels, spinsters and suffragettes}

Women novelists of the 1900s had enacted both formal and thematic innovations that were developed and re-interpreted by neo-Edwardian and suffrage writers in the following decade. A number of literary critics have enumerated the fresh cast of female characters that populate the Edwardian novel, in light of recent social, educational and employment opportunities for women. Miller has outlined this cast as "the suffragette, the Freewoman, the college girl, the typewriter girl and the spinster". Janice Hubbard Harris has similarly observed that new women-focused genres, notably the divorce novel, emerged in the Edwardian period and included new plot structures, such as the "two-suitor plot". ${ }^{15}$

In fictions of the 1910s, the "spinster" and the "suffragette" are frequently depicted typing in the office, studying at Newnham or Girton colleges, enduring hunger-strikes at Holloway prison and engaging in political debate in town halls and on city streets. Such settings are the novelistic environments for these new Edwardian archetypes. At the level of plot, when contemplating marriage, these heroines are indeed torn between two suitors who represent opposing political views, such as when, for example, Edith Carstairs in Constance 
Maud's No Surrender (1911) renounces an anti-suffrage MP for a man who supports votes for women. However, the shadow of the Victorian angel modifies or transforms these figures. The now-notorious "angel in the house" of the Victorian novel is a less familiar figure in Edwardian fiction, as more heroines venture beyond the house. Furthermore, the connotations of the angelic woman were significantly altered within the representational strategies of the Women's Social and Political Union by Sylvia Pankhurst's “Angel of Freedom”: this visual motif decorated many individual and collective markers of suffragette identity, such as brooches, banners and certificates. As Hester Reeve says, Pankhurst's adaptation and deployment of an Arts and Crafts-inspired image marks her development as a "militant artist": similar to the suffrage novelists and their creation of overtly political narratives, Pankhurst's "political campaigning is infused with artistic labour and a belief in the visual power of images". ${ }^{16}$

The active and heroic angel, linked to historical and mythologised figures such as Joan of Arc, and to transformed visual imagery, appears in women's fictions from the 1910s. The spinster, the suffragette and the angel merge to significantly affect the characterisation and narrative trajectories of the female characters. ${ }^{17}$ The Edwardian angel initially appears in familiar guise: she is virtuous, devout, often impoverished and willing to undergo suffering and sacrifice for others. For example, in Prisons and Prisoners, the narrator encounters "a little girl prisoner. She was not more than a child. For aught I knew she may have been taken straight from the streets, but she had at that moment the face of an angel". ${ }^{18}$ However, this visual symbolism is subverted and modernised in characters who are active in the suffrage cause, rather than passive images of suffering like the "little girl prisoner". Angels are often clad, symbolically, in white. In Edwardian Britain, the white or pastel-coloured "lingerie" dress was a common summer outfit for women of all social classes, and thus did not 
necessarily denote conventional ideas of feminine purity. ${ }^{19}$ Furthermore, the colours of the Women's Social and Political Union were purple, green and white (symbolising royalty, hope and purity). These shifting connotations of whiteness and purity are emphasised in No Surrender, where the suffragettes are "pale as moonlight" and the merging of angel and suffragette is underlined when another character exclaims at the sight of them "speak of the angel and you see her wings!",20

The dichotomous counterpart of the Victorian angel was the madwoman or hysteric, and these feminine stereotypes recur in neo-Edwardian texts from this period: for example, in Ford Madox Ford's The Good Soldier (1915), a young woman in white is objectified by the narrator, as a "vivid white thing", and she is later condemned as a madwoman. Generally, however, there are fewer madwomen in Edwardian and early neo-Edwardian fiction; instead, the suffragette and her common counterpart, the spinster, are frequently accused of lunacy when they express and act out their political beliefs. In No Surrender, the suffragettes are "hysterical, unsexed creatures, with a mania against men"21, thus echoing the anti-suffrage arguments of contemporary figures like Sir Almroth Wright, whose The Unexpurgated Case Against Women's Suffrage (1913), performed a similar conflation in his diagnosis of “militant hysteria".

The class, age, education and political affiliation of the spinster varies in neoEdwardian texts, depending on her plot function. Although Lady Constance Lytton - the model for Lady Geraldine Hill in Suffragette Sally and Mary O’Neil in No Surrender belonged to a wealthy and influential family that owned Knebworth House, as an unmarried daughter, she was, as Sue Thomas emphasises, a representative real-life example of "leisured-class spinsters, unemployed, [unpropertied], unendowed, uneducated, without equipment or training for public service”. These upper-class, philanthropic figures also 
possess angelic qualities which are intensified by the language of suffragette conversion, and the likening of force-feeding in prison to crucifixion. ${ }^{22}$ On the other hand, Miller notes that many Edwardian novels featured university-educated, middle-class women who aimed for professional careers rather than marriage. These figures deliberately obstructed the conventional ending of marriage (in life and in literature) and were often objectified and attacked. Thomas observes that contemporary publications including Punch mocked such women as 'the "embittered spinster" stereotype for women's rights campaigners: "thin, lacking the curves appropriate to pleasurable femininity, motherhood and charm" and wearing "pretentiously "arty", shabby or masculine clothes and probably spectacles". One fictional example is Gertrude Marvell, the leader of the militant "Daughters of Revolt" in Mrs Humphry Ward's anti-suffrage novel, Delia Blanchflower (1914). ${ }^{23}$ A history graduate whose early career in a "dismal type-writing" office leads to a "bitter sense of injustice, on the economic side; remembering fiercely her own stinted earnings", Gertrude develops "that strange, modern thing, a woman's hatred of men - the normal instincts of sex distorted and embittered". Gertrude's anger is associated with fire: "when...a section of the Woman Suffrage movement had broken into flame and violence, she had flung her very soul to it as fuel" - and she finally perishes in a manor-house that has been torched by her militant group, in a scene which echoes the demise of Victorian literature's most famous madwoman, Bertha Rochester from Charlotte Bronte's Jane Eyre. ${ }^{24}$

The association of "embittered" spinsters with education - and in turn, with middleclass status - is explored in several suffragette novels. In No Surrender, one schoolteacher joins the cause when she learns that she is being paid less than her male colleagues and an aristocratic woman singles out this category of suffragette for particular condemnation: "never have I beheld such awful unsexed creatures, and one, if you'll believe me, was a school-teacher". As Sheila Jeffreys has said, the introduction of compulsory secondary 
education near the beginning of the Edwardian period, in 1902, and the development of girls' schools that implemented strong academic curricula, as well as contemporary developments in sexology, led to new depictions of inversion and lesbianism in representations of allfemale environments - or what Heather Julien describes as "lesbophobic and anti-spinster discourse". Again in No Surrender, one aristocratic lady discusses women's adoption of "bourgeois" careers such as law and medicine: declaring grimly, however, that "women of the middle classes can't rise to any sort of distinction...the RAs... are all for men - and quite rightly; otherwise, it would be putting a premium on spinsterhood, which is already a growing danger among girls". ${ }^{25}$

However, one field in which middle-class women graduates could rise to distinction was as head of a girls' school, as in Clemence Dane's Regiment of Women (1917). ${ }^{26}$ As a conservative, yet ambiguous, account of women's changing social roles, this novel's development of Edwardian female characters and plot structures provides a useful counterpoint to pro-suffrage novels, and illuminates many of the personal and social conflicts that these works engage with - notably, the purpose of female education, marriage and women-only organisations. The novel is set in an Edwardian girls' school and the timeline is carefully established through the educational histories of the main characters, which mirror the wider educational changes of the preceding decades. The charismatic thirty-something Clare Hartill gains the headship of a "staid English establishment" in which the "Seminary for Young Ladies of the seventies was three parts obliterated by the nineties High School regimen, on which, in its turn, was superimposed the cricket and hockey of the twentieth century's effemination of the public school system". ${ }^{27}$ She promptly dismisses forty-sevenyear old Miss Vigers, who was "hardly the woman for a modern house-mistress-ship...old fashioned....in these days of degrees and college training", in favour of a "suitable woman" from Newnham College. Clare's favourite young teacher, eighteen-year-old Alwynne, travels 
to the countryside and observes the regime of Dene Compton, a co-educational school. As Alwynne's allusion to "cranks and simple lifers and socialists" indicates, these educational ideas were often associated with contemporary socialist organisations and indeed, her new friend at Dene, Roger Lumsden, is described as "Fabian in his methods". ${ }^{28}$ Such organisations were not necessarily progressive in their visions of women's future roles, and Alwynne is informed that girls take "needlework classes, and housewifery" and learn "practically...everything else" with the boys, although this is not elaborated on. Now a "different girl" at Dene Compton, she is receptive to the advances of Roger, who agrees that a regiment of women is unhealthy: "such a lot of women at close quarters, all enthusiasm and fussing and importance"; and he explicitly condemns Clare as an undesirable maternal educator: "he was horrified at the idea of...such a type of woman, in undisputed authority, moulding the mothers of the next generation".

As Alison Hennegan says, spinsters are often depicted as exploiting other women through their professional power, thus threatening heteronormative order. ${ }^{29}$ Clare is an "abnormal, spiritually perverse" figure who ends the novel in her lonely flat facing a future of “work and loneliness". Given this ending, Aunt Elsbet's ominous prophecy seems to exclude Clare from the group of exceptional spinsters whose existences are justified: "the brilliant woman - the rich woman... but when her youth is over, what is the average single woman?...we both know that an unmarried woman - she's a failure - she's unfulfilled". Sowon Park has stated that novels with anti-suffrage themes usually depict an unsexed virago figure - a suffragette - as a foil in a romance plot in which the feminine protagonist Alwynne - finds fulfilment in a heterosexual relationship. ${ }^{30}$ However, Clare is not characterised as a suffragette and it is only during two episodes that the suffrage question is discussed. Alwynne expresses outrage to her male lover "over the conduct of a certain Cabinet Minister - he won't even see them...not even a deputation from the constitutional 
section! Just because some women are fools - and burn things -“. He notes inwardly that she “re-hashes Mona Hamilton's arguments". As well as another means of dating the novel, this conversation obliquely states the novel's position on women's suffrage. "Mona Hamilton" may be a reference to a music teacher who briefly appears in the novel as the 'level-headed and convincing speaker' Miss Hamilton. She is a "law-abiding suffragist" who, as a visiting mistress, is not enmeshed in the unhealthy "school interdependencies" and she "crashed through pedestals", whereas headmistress Clare is Minerva, or Diana - an "Olympian”, or a pagan variation on the Edwardian angel - to whom the school prays. Thus, The Regiment of Women offers a brief affirmative portrait of a spinster who is politically engaged and reformist, but whose deference to conventional legal and social structures means that her story does not disrupt the formal resolution of the novel. ${ }^{31}$

\section{Neo-Edwardian suffragette narratives: history/autobiography/fiction}

Despite the evident influence of the Edwardian novel on suffragette fiction, and the writers' development of formal and thematic structures for their political purposes, scholars from recent decades have addressed what Norquay and Park have observed as - "the problem for literary critics, confronted with literature which was clearly aimed to have a particular effect on an audience, which deliberately used specific historical detail" 32 - by producing anthologies of suffragette texts that encourage new ways of reading, and map new networks and collaborations. For example, Katharine Cockin, Glenda Norquay and Sowon S. Park have edited Women's Suffrage Literature, a six-volume collection that focuses on suffrage "literature", but they employ a deliberately broad definition to enable, for example, the inclusion of privately printed works as well as better-known novels, and to indicate the intertextual relationships between different categories of literary production. Volume Two is dedicated to the "Fiction of Gertrude Colmore" and expands our understanding of Colmore's thematic and formal choices as a novelist, by exploring her stylistic development in short 
stories from suffrage periodicals including The Suffragette and Votes for Women. Unsurprisingly, suffrage writers have received considerable attention from women's history scholars - notably, in several special issues of Women's History Review, including a 2018 volume to memorialise the 1918 Representation of the People Act - who seek both to uncover the specific details of "ordinary" women's lives and to re-write existing historical narratives. ${ }^{33}$ The shared commitment of literary critics and historians to create new narratives and new epiphanic moments - to present, for example, as Cockin, Norquay and Park state in their General Introduction, "novels, short stories and plays in the anthology [that] cover a range of key moments" - has led to collaborations between scholars from both disciplines to uncover the literary and discursive strategies in a range of "non-literary" texts from the period. Two major anthologies - Valerie Sanders and Lucy Delap eds. Victorian and Edwardian Anti-Feminism. 4 vols. (London: Routledge, 2010\} and Ann Heilmann and Lucy Delap eds. Anti-Feminism in Edwardian Literature. 3 vols. (London: Continuum, 2006) - republish contemporary essays and reviews from periodicals dealing with a wide range of subjects including literature, science and politics. Some of the essayists and reviewers who are included in these anthologies - including Mrs Humphry Ward, Cicely Hamilton and May Sinclair - also discussed the suffrage question in their novels, so it is instructive to build on this work by recent editors to consider how Colmore and Maud engaged with contemporary issues and exploited the literary potential of these genres. ${ }^{34}$ This development of genres by suffrage writers has been another important focus for both historians and literary critics: as Kabi Hartman observed in the 1998 special issue of Women's History Review: "generic forms themselves are not fixed, but rather, can be affected by specific political and gender concerns as well as by the social and cultural milieu". ${ }^{35}$ 
The novels engage with contemporary concerns about degeneration and women's role as mothers of the race/nation, for example, and in an essay for the English Review, May Sinclair claimed that woman "is profoundly conscious of her Race... whose guardian and saviour she is". ${ }^{36}$ In No Surrender, one character recalls a political speech in which it was claimed "that to admit Women to the Suffrage would mean the inevitable decadence and degradation, not only of our national life, but of the race". However, both novels transform such imagery, employing contemporary discourses of evolution, and spiritualist and theosophical development, to position women as the vehicles of progress. In Suffragette Sally, the narrator says that "cosmically, they are tools" who embody the "translation of evolutionary law into concrete history'. In the final chapter of No Surrender, a suffrage rally is witnessed by a mysterious Brahmin, who closes the novel by claiming that "they obey a Voice... and they are carried forward on the bosom of the onward flowing river". ${ }^{37}$ Colmore's novel also challenges the "physical force argument" for citizenship, namely that women could not be enfranchised because they did not have sufficient strength to defend their country and to fight in wars. This argument was supported in an essay by Ward, who claimed that "men who are called on to die for England are good enough to vote for her". However, Colmore broadens the definition of just physical force, and of women's capacity for strength and bravery. In a chapter entitled "Cheap Martyrdom", the narrator juxtaposes violent spectacle with the suffragettes' heroic reactions to their treatment by male policemen, minor characters who function as examples of the "extraverted self" whose consciousness represents the wider group identity: “Angela Sayte had stuck as long as she could to Rachel's side, doing her best to protect her...onward went Angela, never ceasing in her efforts"; while in another chapter on the "Black Friday" demonstration, the narrator comments that "women who had been told they must not have the vote because they could not fight, showed they could fight that day" ${ }^{38}$ 
No Surrender engages with claims that women's political enfranchisement will disrupt the gendered organisation of public and private spheres by, for example, encouraging women's greater participation and decision-making in the workforce, and the consequent lowering effect on men's wages. The trade-union leader, Joe, makes several of the set speeches that feature in the novel, mirroring the arguments of periodical essayists. He sets out the local and circumscribed role for women in public institutions: "I' $d$ place some on the Municipal Council, and on vestries" but "I want to see you women and gels leadin' 'appy lives in 'appy 'omes". He expands by adding that "women's sphere is the 'ome, and 'er power lies in influencin' us men". Colmore's novel features similar rhetoric: that "a woman rules by her influence; her weapon is persuasion". ${ }^{39}$ This notion of feminine domestic influence was commonly used to justify women's lack of political power: as Brian Harrison has noted, the private sphere was widened to incorporate only "the political hostess and the female philanthropist”. In 1907, Caroline F. Stephen similarly claimed a role for women in public life that merely extended the scope of their domestic duties: "we desire, while preserving the old domestic ideal, to extend its action beyond the narrow limits of particular families...so as to purify and elevate the whole of our national action through its influence". 40 However, one of the main plotlines in No Surrender - which concerns the powerlessness of a mother to stop her husband from taking her children to another country - humanises the debate and demonstrates the political ineffectiveness of "influence", or "wiles an" smiles" as the heroine's anti-suffrage father terms it, in a nation where legislation is implemented by men. $^{41}$

A common claim of anti-suffrage essayists such as Edith M. Massie was that woman was 'guided by her heart rather than her head' and could not be trusted to make sound political decisions. In "Let Women Say!", Ward projected these gendered discourses on to 
the spectacle of recent suffragette demonstrations to demonstrate their consequent unfitness for the vote: "the history of the WSPU, and of the agitation conducted by them before the War, confirms...the greater excitability and lawlessness of women when subjected to the strain of politics". Other writers used the psychoanalytic language of hysteria, and Violet R. Markham's disavowal of this language indicates its familiarity and power: "anti-suffragists must refrain from...casually writing the word hysteria over a cause supported by women of the finest intellectual power'. ${ }^{42}$

However, Colmore's novel exposes the irrational prejudice of many anti-suffragists when, in a chapter entitled "Bumbledom", a "very measured" account of a suffragette's prison experiences is "denied". The third-person narrator comments ironically that “officialdom consisted entirely of men, and was consequently impartial, unprejudiced and infallible; whereas Lady Henry was a woman and necessarily hysterical". ${ }^{43}$ The fictionalised accounts of suffragette activities that are contained within the novel effectively undermine the equation of emotion with irrational actions, and with women. When Lady Henry (Geraldine) Hill is exposed as the title character of the chapter "The Passing of Mrs Brown" - in which Constance Lytton's speech at the Queen's Hall on 31 January 1910, about her prison experiences as Jane Warton, is recounted - one male character is (irrationally) more outraged by the collapsing of the binary identities that constitute his ideas about femininity, than by Lady Hill’s deception: “she was Lady Henry Hill, of course, a militant suffragette, shameless, unsexed, altogether abominable; and yet, somehow, the woman who presented herself to him was the feminine Mrs Brown". 44

The presence of a fictionalised Lytton in both Maud's and Colmore's novels foregrounds the status of suffragette autobiography in the relationship between fictional and historical narratives, in light of Lytton's subsequent work. While it is not possible to gauge the direct influence of these novels on Lytton, or on contemporary readers of her 
autobiography, the reception of Lytton's work is underpinned by frank, and more covert, assessments of its contribution to, and modification of, historical and literary representations of prisons and suffragettes. As Lytton's title - Prisons and Prisoners: some personal experiences - indicates, her autobiography centres on the identity-changing experience of the prison environment. Contemporary reviewers praised its candour and its investigative quality - "it sheds much-needed light on the hidebound officialdom...this is, perhaps, the first time that the inequalities of treatment...[has] been so clearly expressed in book form" (Athanaeum) - and these reviews continue to be appended to modern editions of the work. Other reviewers assessed the range of generic and disciplinary influences on Lytton's life narrative: it is "not politics, but psychology" (Observer), her work was compared to the "Sacred Books of the race" (Christian Commonwealth), and commended as a recent, and therefore topical, autobiography, with a "factual" basis: "life itself, facts lived and suffered within the last year or two" (Graphic), while some reviews commended both the work's sociological and literary antecedents: "as a piece of literature it is admirable, and as a contribution to our knowledge of what prison life is" (Liverpool Daily Post). ${ }^{45}$

As a recent autobiography, in which the past and the present 'I' almost merge in the final chapters, Lytton's work was perceived to carry the authority of lived experience. Lytton's account provides the continuity of a first-person narrator and the historical detail that the novels present in disguised form, including "real" letters - albeit selected examples which are placed at particular junctures within Lytton's narrative. For example, following her discharge from imprisonment as Jane Warton in 1910, Lytton narrates her dissemination of her experiences to the Times, Votes for Women, and the speech at Queen's Hall which was presented in fictionalised form in Suffragette Sally. While the novel presents her from an external male perspective as a charming and articulate speaker who is rapturously received, Lytton's autobiography emphasises the weakened state that forced her to stand "for an hour 
on one foot" and, in the main body of the chapter, she only chooses to include one document, "Report of Physical Condition of Lady Constance Lytton", by her doctor. ${ }^{46}$ In this chapter and elsewhere, then, Lytton's revelation of her internal state is marked by her use of textual strategies, rather than multiple historical documents, to ground her claims to authority. These strategies also serve to reinforce the strong and consistent narrative viewpoint that the novels lack. Sos Eltis, for example, has recently noted that "Lytton's similes...paint a precise picture, her visual analogies bringing appearances more sharply into focus. Lytton is also particularly careful not to use metaphor to erase distinctions or obscure the particularities of agency", whereas the fictionalised Lytton in Suffragette Sally uses the image of the incoming tide to justify militancy and thus "Colmore, by contrast, repeatedly uses metaphorical language to blur and evade issues of [individual] responsibility". ${ }^{47}$

However, Lytton's narrative voice models several subjectivities that encourage various reader identifications. Despite the sub-title of her autobiography - some personal experiences - the main title, Prisons and Prisoners, has a generalising import, and, indeed, many critics have discussed how Lytton's autobiography became a generic model for suffragette narratives, helping to create a new collective identity which epitomised dislocation from previous environments. ${ }^{48}$ Like the novels, Lytton's work contains a framing narrative, the 'Dedication to Prisoners', which precedes the main text. Unlike Colmore's and Maud's attempts to frame their works' relationship to prevailing definitions of genre or chronology, however, Lytton's preface introduces the work's prevailing model of selfhood. She emphasises each individual's essential self - "lay hold of your inward self, and keep tight hold" - while repeatedly addressing the group, the 'prisoners'. Similarly, the main text emphasises her commitment to representing her suffragette identity as a form of extraverted, relational, but highly individualised, selfhood: "this unity, so far from tending to produce 
uniformity of type, had the very opposite effect, it enhanced individuality". ${ }^{49}$ This model of selfhood is also reinforced by Lytton's textual strategy of shifting between third and first person narration, which has also been read as evidence of a psychological split, or an effect of Lytton's dual identity as Jane Warton. ${ }^{50}$

Taken together, the novels and Lytton's autobiography re-write the conventional life history of the Edwardian heroine. All three works create epiphanic moments which also revise the conventional key dates of the Edwardian decade. These includes the muchdiscussed moment of conversion to the suffrage cause, which is precisely dated in Lytton's autobiography: the chapter entitled "My Conversion" notes of this momentous event that "it was in August-September 1908" and she becomes a member of the WSPU in February 1909. This new suffragette identity marks a rite of passage when she leaves the home of her (conventionally Edwardian) "angel mother". ${ }^{51}$ In Colmore's novel, another major life event is the first police arrest: this chapter, "Arrested", begins "it was the 24 February 1909", while 13 October 1905 is memorialised as the day of Annie Carney's (Kenney) speech at the Free Trade Hall in Manchester. Similarly, in No Surrender, the working-class suffragette Jenny's development is measured by the narrator's observation that "a year had passed by since Jenny enlisted in the fighting army". 52

The "Black Friday" march to Parliament, on 18 November 1910, to protest at Prime Minister Asquith's abandonment of the Conciliation Bill to extend voting rights, is a structural and thematic climax of many suffragette narratives. Such representations emphasise both the collective consciousness that underpins the individual stories, and the new narrative structures that create a range of Edwardian and suffragette femininities. The penultimate chapter of Lytton's autobiography, “The Conciliation Bill” includes an account of the march; a dedicated chapter, "Black Friday" is also placed near the end of Suffragette Sally. Lytton's account is a detailed description of the preceding events in Parliament, the 
contents of the Bill, the participants in the Deputation to Asquith, and reproductions of relevant letters by Lord Robert Cecil and Lord Lytton to Asquith. It is at this point that Lytton's work reads most like an historical narrative, with the narrator situated as a privileged eyewitness who is marginalised by patriarchal institutions but whose limited access enables her to be a (subversive) chronicler of official history.

By contrast, in the novels, both Black Friday, and other major suffragette demonstrations, are key sites for the development of representational strategies to re-shape perceptions of the era, and of the ordinary suffragette life history. In No Surrender, the concluding chapter, "The Passing of the Women", re-creates the WSPU demonstration of 18 June 1910, when nearly 15,000 women marched from the Embankment to the Albert Hall to hear speeches from Christabel Pankhurst and other suffragette leaders. The Edwardian summer motif is used by Maud to develop the connotations of purity that were attached to the WSPU usage of white. In women's suffrage demonstrations, ex-prisoners pointedly wore white clothes. Lytton claimed that "a rapid means of irrepressible communication had to be sought through the symbolism of colours, purple, white and green - justice, purity, hope", but Hilda Kean has also noted that "the very inclusion of words ensured another layer of meaning; the words became an integral part of the action. The theatrical nature of words... was used to create a performative discourse - and a feminist identity". ${ }^{53}$ These novels, then, expand the symbolism of WSPU colours through words, and our understanding of the use of spectacle in the movement.

In No Surrender, during the June 1910 demonstration, the novel depicts a "white-clad band of women and girls of all classes, bearing proudly as the very crown and glory of their womanhood, the prisoner's badge of disgrace". This is the culmination of the revision of such imagery throughout the novel, where the working-class suffragettes Mary and Jenny are consistently depicted taking radical action in white: "both wore cool white dresses and little 
badges of the violet and green Union colours" and "many rustic eyes gazed admiringly at the three young women in their fresh cotton dresses - Jenny in lilac, Hilda in green, and Nurse Dodds in her white hospital uniform, all with conspicuous badges of the Union colours, bearing the device "Votes for Women". Similarly, in Colmore's novel, the working-class suffragette Sally is described by onlookers in transformative language when, at "The Truce" suffrage meeting, "there she was, in the very head of the great procession, amongst them ladies...they had looked, half in admiration, and half in mockery, at Sally in her white dress". 54

These transformed "ordinary" suffragettes, then, ultimately displace the well-known heroines of the cause, such as Florence Nightingale, Joan of Arc and Charlotte Corday. In No Surrender, for example, one character declares of Jenny that "she is more like my idea of the peasant aid Jeanne d'Arc, than anyone I ever met. She has heard a voice, that girl, telling her to come out and fight for a sacred cause, and she is ready to die for freedom and justice". These suffragettes become Edwardian versions of the archetypal figures of warrior and nurturer - rather than passive suffering angels and spinsters - who are firmly rooted in the social conditions of the present. The emphasis on Joan of Arc's "peasant" background further validates working-class Jenny's heroism. Other well-known narratives are also feminised and modernised for the Edwardian era. No Surrender consistently cites recent literary women as inspirational figures, but instead of valorising the great Victorian heroines, the victims of Victorian fictional juries are memorialised: Walter Scott's Effie Deans, George Eliot's Hetty Sorrel "and all the long, sad procession of victims" of male-only juries. ${ }^{55}$

There are also other, more subversive, stylistic decisions. Colmore's work places epigraphs at the beginning of chapters, which was a common device in the nineteenth-century novel. However, several scholars have noted the adoption of this device by neo-Victorian writers, who exploit the epigraph's intertextual possibilities to create an "alternate but in 
some way connected world-vision into the text”. Similarly, Colmore's neo-Edwardian text often uses epigraphs from recent texts to foreground the victims of current legal structures. For example, the prison chapters 16,17 and 38 are preceded by epigraphs from Oscar Wilde's “The Ballad of Reading Gaol”. By juxtaposing the suffragette prisoners with a fictionalised life narrative by a subversive aesthete who challenged late Victorian gendered and sexual identities, the novel works both to vindicate Wilde and to underscore the radicalism of the suffragettes' challenge to Victorian and Edwardian feminine identities. In No Surrender, the novel's debt to literary history is linked more explicitly to the novel's theme of (literary) evolution, when the narrator reflects on a suffrage demonstration: "thus have Jane Austen's sweet, sensitive English maidens, who went into fits of hysterics at sight of a mouse, been transformed by a process of rapid evolution and adjustment to a new environment", 56

This passage serves as a metanarrative reflection - characteristic of both neoVictorian and neo-Edwardian texts - on the shaping powers of texts in the construction of identities and periods. These suffragette narratives, then, can be read as a re-evaluation of the Edwardian era, as texts which re-write the age in terms of the militant struggle for female citizenship. In doing so, these texts privilege women's experiences and make their own challenge to hierarchies of genre, theme and literary history, by providing new models of selfhood and narrative structures which are developed from a range of textual sources and, when read together, further illuminate the debates and inter-textual influences within the suffragette movement. Thus, reading suffrage narratives of the 1910s as neo-Edwardian narratives provides new ways of reading modern, and modernist, literary history. 
${ }^{1}$ See Mary Joannou, "My Part in a Changing World": Women's Struggle for the Vote and the Autobiographical Subject", Women's Writing, 25.3 (2018): 294-313. Joannou observes that "the suffrage campaigns bifurcated women's lives into a modern "after" and a Victorian and Edwardian "before"'. See, for example, Dora Montefiore, From a Victorian to a Modern (London: E. Archer, 1927).

${ }^{2}$ Sarah Edwards, "The Rise and Fall of the Forsytes: from neo-Victorian to neo-Edwardian marriage", NeoVictorian Families: Gender, Sexual and Cultural Politics, ed. Marie-Luise Kohlke and Christian Gutleben (Amsterdam \& New York: Rodopi, 2011), pp. 197-220; Sarah Edwards, "Dawn of the New Age: NeoEdwardian and Edwardian Summer", Edwardian Culture: Beyond the Garden Party, ed. Samuel Shaw, Sarah Shaw and Naomi Curle (Abingdon: Routledge, 2017), pp. 15-30.

${ }^{3}$ For example, May Sinclair's The Tree of Heaven (1917) uses the multi-generational family saga to set the parameters of the Edwardian age (1895-1916). For recent debates on the parameters of the Edwardian period, see Ann Ardis, Modernism and Cultural Conflict, 1880-1922 (Cambridge: Cambridge University Press, 2002); Robert Caserio, "Edwardians to Georgians", The Cambridge History of Twentieth-Century English Literature ed. Laura Marcus and Peter Nicholls (Cambridge: Cambridge University Press, 2005): pp. 83-99; Anne Fernihough, Freewomen and Supermen: Edwardian Radicals and Literary Modernism (Oxford: Oxford University Press, 2013), p. 14; Laura Marcus, Michèle Mendelssohn, and Kirsten E. Shepherd-Barr, eds., Late Victorian into Modern (Oxford: Oxford University Press, 2016); Jonathan Wild, Literature of the 1900s: The Great Edwardian Emporium (Edinburgh: Edinburgh University Press, 2017).

${ }^{4}$ See also the useful definition of neo-Victorian fiction in Mark Llewellyn and Ann Heilmann, NeoVictorianism: The Victorians in the Twenty-First Century (Basingstone: Palgrave Macmillan, 2010). Other early examples of neo-Edwardian texts are Rebecca West, The Return of the Soldier (1918), Cicely Hamilton, William: An Englishman (1919).

${ }^{5}$ For example, E. M. Forster, Howards' End (1910), which conflates the country house, June and social change; the wood and the "Sacred Lake" in Forster's A Room with a View (1908); and the neo-Edwardian texts, A. S. Byatt, The Children's Book (2008), Alan Hollinghurst, The Stranger's Child (2011). See also Fernihough (p. 14) on the country house and popular imaginings of the Edwardians.

${ }^{6}$ Gertrude Colmore, Suffragette Sally, in Katharine Cockin, Glenda Norquay and Sowon S. Park, eds., vol. 2 of Women's Suffrage Literature (London: Routledge, 2007), p. 253.

${ }^{7}$ See, for example, H.G Wells, The Passionate Friends (1912); ibid, pp. 67-68, 324.

${ }^{8}$ See Jane Eldridge Miller, Rebel Women: Feminism, Modernism and the Edwardian Novel (Chicago: University of Chicago Press, 1997), who notes the "multiple, intertwining narratives" in suffragette novels, which enable the voices of women and men with differing views, through the rendition of conversations, letters, songs, such as the suffragette marseillaise (p. 145).

${ }^{9}$ For example, Julian Barnes, Arthur and George (2005) depicts the real-life encounter between Arthur Conan Doyle and an Edwardian solicitor; Penelope Fitzgerald, The Gate of Angels (1990) depicts the 1909 opening of Selfridge's department store; John Galsworthy's In Chancery (1920) is set in 1899-1901, and the work depicts the 1901 Coronation and the cultural import of the shift from the Victorian to the Edwardian age.

${ }^{10}$ Constance Maud, No Surrender: a novel of the suffrage movement (Endeavour Publishing: Kindle Edition, 2015), loc. 34.

${ }^{11}$ Sowon S. Park, "Suffrage Fiction: A Political Discourse in the Marketplace", English Literature in Transition, 1880-1920, 39.4 (1996): 450-56 (451); Sos Eltis,"A class act: Constance Lytton and the political, literary and dramatic dynamics of prison suffrage writings", Feminist Modernist Studies, 2.1 (2019): 1-20 (3).

${ }^{12}$ Pykett notes that some earlier scholars concurred with Virginia Woolf's influential essay "Mr Bennett and Mrs Brown" (1924) that "1910 has a certain plausibility as the founding year of English modernism", other scholars pinpoint 1908, 1900 and periods from 1890-1910 to 1907-25 as key dates for literary modernist development (Lyn Pykett, Engendering Fictions: The English Novel in the Early Twentieth Century (London: St Martin's Press, 1995, p. 8). Fernihough has noted that, as a literary term, the "Edwardian" has been generally conflated with realism, but she notes that scholars from the later twentieth century onwards have increasingly rejected "any clear-cut realist/modernist divide" and interrogated relationships between realist/modernist form 
and content, and the definitions of the terms themselves. Writing in 1996, Kaplan and Simpson, for example, noted that the "Georgians" "self-consciously set themselves apart" from a "composite Bennett-GalsworthyWells caricature" of "Edwardian liberals obsessed with thematic issues at the expense of artistic considerations" (Carola M. Kaplan and Anne B. Simpson, "Edwardians and Modernists: Literary Evaluations and the Problem of History", Seeing Double: Revisioning Edwardian and Modernist Literature ed. Carola M. Kaplan and Anne B. Simpson (St Martin's Press, 1996, p. viii).

${ }^{13}$ Miller, pp 7-8.

${ }^{14}$ See Urmila Seshagiri, "Making it New: Persephone Books and the Modernist Project", MFS Modern Fiction Studies, 59.2 (2013): 241-87, which considers how feminist modernist scholarship and presses have expanded definitions of modernism to include overlooked subjects and forms such as domesticity and "middlebrow" writing and relations between literary, popular and visual cultures, and includes a reading of No Surrender.

${ }^{15}$ Miller, pp. 84, 4; Janice Hubbard Harris, Edwardian Stories of Divorce (New Brunswick: Rutgers University Press, 1996), p. 11. May Sinclair's Dorothea in The Tree of Heaven follows the typical life narrative of the radical Edwardian heroine: a degree at Newnham College, membership of a militant suffrage organisation led by the Blathwaites (Pankhursts) and imprisonment in Holloway.

${ }^{16}$ Hester Reeve (2014), "The Suffragette as a Militant Artist", Sylvia Pankhurst Memorial Lecture, edited transcript available at http://sylviapankhurst.gn.apc.org/2014\%20lecture $\% 20$ for $\% 20$ website.pdf; see also Maroula Joannou, "The angel of freedom: Dora Marsden and the transformation of the freewoman into the egoist”, Women's History Review, 11:4 (2002): 595-611.

${ }^{17}$ Emmeline Pethick Lawrence said of Lytton in an editorial for the 28 January 1910 issue of Votes for Women: "it is ... as though an angel had visited this sin-stained, sorrow-stricken earth". See E. M. Forster, Where Angels Fear to Tread (1905); for later neo-Edwardian examples, see Penelope Fitzgerald, The Gate of Angels (1990), featuring St Angelicus college and nurse Daisy, a "ministering angel"; Tracy Chevalier, Falling Angels (2001) in which Victorian cemetery sculpture and astronomy are used to explore the title concept.

${ }^{18}$ Lady Constance Lytton and Jason Haslam, Prisons and Prisoners: some personal experiences (Broadview Press, Kindle Edition, 2008), loc. 3237. Lytton also critiques the man-made angels of classical art: "women that were ethereal, but so little real, with a look of purity that no living creature has" (loc. 2299).

${ }^{19}$ Sarah Edwards, "Clad in Robes of Virgin White": The Sexual Politics of the Lingerie Dress in Novel and Film Versions of The Go-Between”, Adaptation: A Journal of Literature on Screen Studies, 5.1 (2012): 18-34.

${ }^{20}$ Maud, p. 32.

${ }^{21}$ Ibid, pp. 46, 52; Ford, p. 101.

${ }^{22}$ Lady Constance Georgina Bulwer-Lytton (1869-1923). See Sue Thomas, "Scenes in the writing of 'Constance Lytton and Jane Warton, spinster': contextualising a cross-class dresser", Women's History Review, 12:1 (2003): 51-71 (54-55).

${ }^{23}$ Miller, p. 87; Thomas, pp. 59, 69; Mrs Humphry Ward, Delia Blanchflower (Amazon Media: Kindle Edition, 2015).

${ }^{24}$ Ward, loc. 2676. Her novel invokes the spirit of England, symbolised by the country house, and uses the metaphor of housekeeping to indicate woman's role. It can be usefully analysed as a descendant of a tradition of Victorian women's writing outlined in the seminal feminist account by Sandra M. Gilbert and Susan Gubar, The Madwoman in the Attic: The Woman Writer and the Nineteenth-Century Literary Imagination (New Haven: Yale University Press, 1979).

${ }^{25}$ Maud, pp, 204, 58, 31. In 1872, the Girls' Public Day School Company had been formed to create secondary schools that would provide a reasonably priced academic education for girls. See also Sheila Jeffreys, The Spinster and her Enemies: Feminism and Sexuality, 1880-1930 (North Geelong: Spinifex Press, 2003) and Heather Julien, “School Novels, Women's Work and Maternal Vocationalism”, NWSA Journal, 19.2 (2007): 125.

${ }^{26}$ Clemence Dane, The Regiment of Women (OTB Publishing, Kindle Edition, 2017). Julien also discusses the professionalization of teaching. New teacher training colleges for women were formed following the 1870 Education Act and the consequent demand for teachers; teaching was a respectable career for middle-class single women. Contemporary fictional examples of women's teacher training can be found in Thomas Hardy's Jude the Obscure (1895) and D. H. Lawrence's The Rainbow (1915). 
${ }^{27}$ Many of the GPDS girls' schools adopted public-school conventions, including a strong emphasis on sport. See Sally Mitchell, The New Girl: Girls' Culture in England, 1880-1915 (New York: Columbia University Press, 1995), on the impact on middle-class femininity.

${ }^{28}$ Dane, loc. 4196, 490, 6094. Dene Compton may be a fictionalised model of Bedales, which was founded in 1893 and became fully co-educational by 1898: similarly, Dene Compton is "the thin end of the co-educational wedge... unique - or was, until a few years ago... you ladies' seminaries should be trembling in your shoes" (4346). See J.H. Bradley, Bedales: A Pioneer School (London: Methuen, 1923); Sally Alexander, Women's Fabian Tracts (London: Routledge, 1988); Fernihough (p. 5) on the "two socialisms" of the period, including Clarion socialism and its focus on personal liberty and spiritual growth.

${ }^{29}$ Dane, loc. 4435, 6002, 5017. Alison Hennegan, "Introduction", The Regiment of Women (London: Virago Press, 1995), pp. v-xiii.

${ }^{30}$ Park, pp. 455; Dane, loc. 5831, 6868, 4243. Other novels with more ambiguous stances on female suffrage include H.G Wells, Ann Veronica (1909) and Anon, The Home-Breakers (1913).

${ }^{31}$ Dane, loc. 4614, 300, 1319, 1307. Mona Hamilton may be an amalgamation of Mona Caird and Cicely Hamilton, and this amalgamation may allude to Caird's 1908 essay, "Militant Tactics and Women's Suffrage". Alwynne could be referring to several deputations made by suffragettes to Prime Minister H.H. Asquith, in June 1909 and on Black Friday (18 November 1910), although the reference to arson suggests a later date when the militant action has escalated, such as the Great Pilgrimage of 8 May 1913 (when he did agree to meet with suffragist leaders).

${ }^{32}$ Glenda Norquay and Sowon S. Park, “Mediating women's suffrage literature”, Women's Studies International Forum, 29 (2006): 301-306 (304). See also Park: "the ebbs and flows of women's literary production do not necessarily converge with those of canonical literary history....and...leave intact criteria which may exclude the more significant and fundamental points in women's literary history" (p. 459).

${ }^{33}$ See Laura E. Nym Mayhall, "Creating the 'Suffragette Spirit': British Feminism and the Historical Imagination", Women's History Review, 4.3 (1995): 319-44 and recent special issues of Women's History Review: 12.1 (2003) and the women's suffrage centennial special issue (2018).

${ }^{34}$ Valerie Sanders and Lucy Delap eds. Victorian and Edwardian Anti-Feminism. 4 vols. (London: Routledge, 2010\}; Ann Heilmann and Lucy Delap eds. Anti-Feminism in Edwardian Literature. 3 vols. (London: Continuum, 2006); Cockin, Norquay and Park eds. Women's Suffrage Literature. 6 vols. (Abingdon: Routledge, 2007).

${ }^{35}$ Kabi Hartman, "What made me a suffragette': the new woman and the new (?) conversion narrative", Women's History Review, 12:1 (2003): 35-50 (36).

${ }^{36}$ May Sinclair, “A Defence of Men”, The English Review (May 1912): 556-66 (564) in Sanders and Delap. See Fernihough (p. 30) on contemporary debates on "evolutionary optimism".

${ }^{37}$ Maud, pp. 258, 374; Colmore, pp. 98, 279. The role of the Brahmin may be traced to theosophical interests in Eastern spirituality. In 1911, Jiddu Krishnamurti became a speaker for the Theosophical Society in England, and he was hailed as a future "World Teacher" by Annie Besant. For the background to the movement, and its gendered, classed and imperial connotations, see Diana Basham, The Trial of Woman: Feminism and the Occult Sciences in Victorian Literature and Society (Basingstoke: Palgrave Macmillan, 1992).

${ }^{38}$ Colmore, pp. 48-49, 312, 307; Mary A. Ward, "Let Women Say! An Appeal to the House of Lords", The Nineteenth Century and After (January 1918), pp. 47-59 in Sanders and Delap; on "physical force", see Brian Harrison, Separate Spheres: The Opposition to Women's Suffrage in Britain (London: Croon Helm, 1978), p. 78.

${ }^{39}$ Maud, pp. 80, 200.

${ }^{40}$ Caroline E Stephen, "Women and Politics", The Nineteenth Century and After (February 1907), pp. 226-27; Harrison, p. 80. 'Similarly, women should have "the greatest possible intellectual expansion so that she may use it to make her home more gracious, her mateship more complete, her motherhood more perfect", "Is the New Woman Helping Woman?", The National Review, 55, no 328 (1910): 640-45, in Sanders and Delap. S ${ }^{41}$ Maud, p. 80. The novel also engages with issues that concerned working-class women, such as the attitudes of male socialists to women's wages, and women's position in marriage (see references to the Married Women's Property Act, pp. 136, 186). 
${ }^{42}$ Edith M. Massie, “A Woman's Plea against Woman Suffrage”, The Nineteenth Century and After (March 1908), pp. 381-85; Ward, op cit; Violet R. Markham, "A Promised Women's Council”, The National Review (August 1910), pp. 1029-38, in Sanders and Delap.

${ }^{43}$ Colmore, p. 285.

${ }^{44}$ Ibid, p. 221.

${ }^{45}$ Lytton and Haslam, appendix. See also Jason Haslam, "Being Jane Warton: Lady Constance Lytton and the Disruption of Privilege", Captivating Subjects: Writing, Confinement, Citizenship, and Nationhood in the Nineteenth Century, ed. Jason Haslam and Julia M. Wright (Toronto: University of Toronto Press, 2005). ${ }^{46}$ Lytton, loc. 3401.

${ }^{47}$ Eltis, pp. 5-6.

${ }^{48}$ Hilda Kean, "Some problems of constructing and reconstructing a suffragette's life: Mary Richardson, suffragette, socialist and fascist", Women's History Review, 7:4 (1998): 475-493; and see Hartman, 29-30. ${ }^{49}$ Lytton, loc. 14, 59, 593. See Nym Mayhall's influential essay, which argues that "the argument implicit in Lytton's account is that one trajectory of experience alone constitutes authentic suffrage militancy" (324-25) which has influenced subsequent narratives and their reception.

${ }^{50}$ See Eltis, pp. 12-13; as Hartman says, "suffragette conversion narratives sometimes centre on an upper- or middle-class woman's encounter with a working-class woman or woman-in-distress", such as Elizabeth Robins, The Convert (1907).

${ }^{51}$ Hartman also discusses the use of conversion narrative and spiritual autobiography: chapter 13 of Suffragette Sally is entitled "The Sign of the Cross". Lytton, loc. 124, 375.

${ }^{52}$ Colmore, p. 97; Maud, p. 167; Carney is a fictional version of Annie Kenney (1879-1953), a member of the WSPU from a working-class background.

${ }^{53}$ Lytton, loc. 769; Hilda Kean, "Public History and Popular Memory: issues in the commemoration of the British militant suffrage campaign", Women's History Review, 14.13-14 (2005): 583; see Lisa Tickner, The Spectacle of Women: Imagery of the Suffrage Campaign (London: Chatto and Windus, 1987).

${ }^{54}$ Maud, pp. 364, 175, 207; Colmore, p. 289.

${ }^{55}$ Maud, pp. 50, 349.

${ }^{56}$ Colmore's epigraphs quote from the works of many female authors, including Elizabeth Barrett Browning, Charlotte Bronte and George Eliot. Sudha Shastri, Intertextuality and Victorian Studies (London: Orient Longman, 2001), p. 121; see also Deborah Bowen, "The Riddler Riddles: Reading the Epigraphs in John Fowles's The French Lieutenant's Woman", The Journal of Narrative Technique, 25.1 (1995): 67-90 and "reverse reading"; and Christian Gutleben, Nostalgic Postmodernism: The Victorian Tradition and the Contemporary British Novel (Amsterdam: Rodopi, 2001) and the "liminal quotation". Maud, p. 144. 